\title{
Analysis of Triterpenoids in Ganoderma lucidum Using Liquid Chromatography Coupled with Electrospray Ionization Mass Spectrometry
}

\author{
Min Yang, Xiaoming Wang, Shuhong Guan, and Jiameng Xia \\ Shanghai Research Center for TCM Modernization, Shanghai Institute of Materia Medica, Shanghai Institutes \\ for Biological Sciences, Chinese Academy of Sciences, Shanghai, China
}

\section{Jianghao Sun and Hui Guo}

The State Key Laboratory of Natural and Biomimetic Drugs, School of Pharmaceutical Sciences, Peking University, Beijing, China

\section{De-an Guo}

Shanghai Research Center for TCM Modernization, Shanghai Institute of Materia Medica, Shanghai Institutes for Biological Sciences, Chinese Academy of Sciences, Shanghai, China

Triterpenoids extracted from Ganoderma lucidum (Leyss. ex Fr.) Karst were separated and characterized using optimized reversed-phase liquid chromatography with diode array detection and electrospray ion trap tandem mass spectrometry (HPLC-DAD-ESI-MS ${ }^{\mathrm{n}}$ ). They could be classified into five types depending on the fragmentation behavior. All triterpenoids gave $[\mathrm{M}-\mathrm{H}]^{-}$and $[2 \mathrm{M}-\mathrm{H}]^{-}$ions by electrospray ionization monitored in the negative ion mode; in addition, compounds of types III and IV gave prominent $\left[\mathrm{M}-\mathrm{H}-\mathrm{H}_{2} \mathrm{O}\right]^{-}$ions and the unsaturated bond at $\mathrm{C}-20,22$ would reduce the abundance of $\left[\mathrm{M}-\mathrm{H}-\mathrm{H}_{2} \mathrm{O}\right]^{-}$ion. The key fragmentation information was cleavage at $\mathrm{C}$ - and D-rings despite the predominant losses of $\mathrm{H}_{2} \mathrm{O}$ and $\mathrm{CO}_{2}$. Compounds with hydroxyls at C-7 and C- 15 would produce a list of $\mathbf{b}, \mathbf{b}-1$, $\mathbf{b}-2$, and $\mathbf{b}-16$ ions attributed to cleavage of D-ring; if the second alcohol at C-15 were oxidized to ketone, the prominent cleavage would occur at C-ring and produce a group of ions of a; if C-7 were oxidized to ketone, transference of two hydrogen atoms would occur during the cleavage of rings and a list of ions about $\mathbf{a}+2$ and/or $\mathbf{b}+2$ would appear instead. The above fragmentations and regularities in fragmentation pathways were reported for the first time, and were implemented for the analysis of triterpenoids in G. lucidum. The chloroform extract was separated on a Zorbax SB- $\mathrm{C}_{18}$ column, eluting with an acetonitrile- $0.2 \%$ acetic acid gradient. A total of 32 triterpenoids, including six new ones, were identified or tentatively characterized based on the tandem mass spectra of the HPLC peaks. (J Am Soc Mass Spectrom 2007, 18, 927-939) (C) 2007 American Society for Mass Spectrometry

G anoderma lucidum (Leyss. ex Fr.) Karst, a medicinal fungus called "Lingzhi" in China, is a commonly used Chinese herb and an important ingredient in traditional Chinese medicine herbal formulations for the prevention and treatment of various types of diseases, such as cancer, hepatopathy, arthritis, hypertension, neurasthenia, debility, etc. Lingzhi has long been used as a folk remedy for promotion of health and longevity in China and other oriental countries. The most attractive character of this kind of medicinal fungus is its immunomodulatory and antitumor activities [1-7].

Published online March 26, 2007

Address reprint requests to Professor De-an Guo, Shanghai Research Center for TCM Modernization, Shanghai Institute of Materia Medica, Chinese Academy of Sciences, Guo Shoujing Road 199, Zhangjiang, Shanghai 201203, P. R. China. E-mail: gda5958@163.com
Clearly, the activities of G. lucidum are mainly due to polysaccharides and/or triterpenoids of the fungus. Over 130 triterpenoids have been isolated from the fruiting bodies, cultured mycelia, and spores during the past two decades $[8,9]$. Some of the triterpenoids showed antiandrogenic [10], antihepatitis B [11], antioxidant [12,17], antitumor [13, 15], anticomplement [14], antimicrobial [16], anti-HIV-1 [18], selectively inhibit eukaryotic DNA polymerase [19], and angiotensin converting enzyme-inhibitory activities [20]. Thus, a valuable and convincing method for characterization of triterpenoids of G. lucidum is necessary for quality control of the herbal medicine.

Mass spectrometry is the most selective technique for the rapid qualitative determination of known compounds as well as the identification of unknown com- 
pounds from extracts of natural products [21-24]. Some methods were established for separation and detection of triterpenoids in G. lucidum [25, 26]. In this study, an integrated approach consisting of LC/ESI-MS and tandem mass spectrometry $\left(\mathrm{MS}^{\mathrm{n}}\right)$ has been used for the identification of triterpenoids in G. lucidum extracts. To the best of our knowledge, we report here for the first time a comprehensive analysis for the triterpenic acids occurring in G. lucidum based on $\mathrm{MS}^{\mathrm{n}}$ technique. Using ESI-MS, it has been possible to obtain structurally significant fragmentation ions of triterpenoids. The present approach could be applied to studies of triterpenoids in crude extracts of G. lucidum. A total of 32 compounds were identified or tentatively characterized from the chloroform extract of G. lucidum (Figure 1, Table 1); six of them are reported for the first time.

\section{Experimental}

\section{Chemicals}

Ganoderic acid A, B, $\mathrm{AM}_{1}, \mathrm{C}_{2}, \mathrm{D}, \mathrm{G}, \mathrm{H}, \mathrm{J}, \mathrm{K}$, ganoderenic acid $\mathrm{B}$, and $3 \beta$-hydroxy-4, 4, 14-trimethyl-7, 11, 15-trioxochol-8-en-24-oic acid were isolated from the fruit bodies of G. lucidum. All these structures were fully characterized by direct comparison of their NMR and MS spectra data with those reported in the literatures [27-33]. Their ${ }^{\circ}$ purities were over $95 \%$ determined by HPLC/UV analysis. HPLCgrade acetonitrile $(\mathrm{MeCN})$ (Burdick and Jackson-Honeywell Intl., Muskegon, MI) and ultra-pure water were used for all analyses. The chloroform and methanol for sample preparation and the acetic acid $\left(\mathrm{CH}_{3} \mathrm{COOH}\right)$ used in the mobile phase were of AR grade, purchased from Beijing Chemical Corp. (Beijing, China).

\section{Sample Preparation}

G. lucidum was obtained from the cultivation base of Green Valley Pharmaceutical Co. Ltd. (Shanghai, China). A $2.0 \mathrm{~g}$ powder of dried samples was extracted with $40 \mathrm{~mL} \mathrm{CHCl}$ in an ultrasonic water bath for 20 min. This extraction was repeated twice. The extracted solution was mixed and filtrated through analytical filter paper; then the filtered solution was evaporated at $35^{\circ} \mathrm{C}$ to dryness in vacuum. The dry extract was dissolved in $5 \mathrm{~mL}$ methanol and filtrated through a 0.45 $\mu \mathrm{m}$ membrane filter unit. Then $3 \mu \mathrm{L}$ of each sample solution was analyzed by HPLC.

\section{Chromatography}

The analyses were performed on an Agilent series 1100 HPLC instrument (Agilent, Waldbronn, Germany) equipped with a quaternary pump, a diode-array detector (DAD), an autosampler, and a column compartment. The sample was separated on a Zorbax SB-C 18 column $(5 \mu \mathrm{m}, 4.6 \times 250 \mathrm{~mm}$; Agilent). The mobile phase consisted of acetonitrile $\left(\mathrm{CH}_{3} \mathrm{CN}\right)$ and water containing $0.2 \%$ (vol/vol) $\mathrm{CH}_{3} \mathrm{COOH}$, with a gradient from 30 to $32 \% \mathrm{CH}_{3} \mathrm{CN}$ over the first $40 \mathrm{~min}$, then to $40 \%$ in $20 \mathrm{~min}$, and held at $40 \% \mathrm{CH}_{3} \mathrm{CN}$ for another 5 min. The flow rate was $1.0 \mathrm{~mL} / \mathrm{min}$, and column temperature was set at $35{ }^{\circ} \mathrm{C}$. The DAD detector was monitored at $252 \mathrm{~nm}$, and the on-line UV spectra were recorded in the range of 190 to $400 \mathrm{~nm}$.

\section{Mass Spectrometry}

A Finnigan LCQ Advantage ion trap mass spectrometer (ThermoFinnigan, San Jose, CA) was connected to the Agilent 1100 HPLC instrument via an ESI interface. The LC effluent was introduced into the ESI source in a post-column splitting ratio of 2:1. Ultrahigh-purity helium $(\mathrm{He})$ was used as the collision gas and high-purity nitrogen $\left(\mathrm{N}_{2}\right)$ as the nebulizing gas. The MS detector was optimized by injecting a $5 \mu \mathrm{L} / \mathrm{min}$ flow of triterpenoid standards $(0.1 \mathrm{mg} / \mathrm{mL}$ in methanol) to obtain maximum intensities of $[\mathrm{M}-\mathrm{H}]^{-}$ions. The optimized parameters in the negative ion mode were as follows: ion spray voltage, $4.0 \mathrm{kV}$; sheath gas $\left(\mathrm{N}_{2}\right), 40$ arbitrary units; auxiliary gas $\left(\mathrm{N}_{2}\right), 10$ units; capillary temperature, $270{ }^{\circ} \mathrm{C}$; capillary voltage, $-30 \mathrm{~V}$; tube lens offset voltage, $-25 \mathrm{~V}$. For full scan MS analysis, the spectra were recorded in the range of $\mathrm{m} / \mathrm{z} 80$ to 1200 . A datadependent acquisition was set so that the two most abundant ions in full scan MS would trigger tandem mass spectrometry ( $\mathrm{MS}^{\mathrm{n}}, n=2$ to 4 ). The collision energy for $\mathrm{MS}^{\mathrm{n}}$ was adjusted to $41 \%$ in LC/MS analysis, and the isolation width of precursor ions was $3.0 \mathrm{~m} / \mathrm{z}$.

\section{Results and Discussion}

\section{ESI-MS ${ }^{n}$ Analysis of Pure Standards}

ESI-MS spectra in both negative and positive modes were examined in this study. Negative mode ESI was found to be sensitive for triterpenic acids. Pure compounds (0.1 $\mathrm{mg} / \mathrm{mL}$ in $\mathrm{MeOH}$ ) were injected into the ESI source by continuous infusion. All triterpenoids gave $[\mathrm{M}-\mathrm{H}]^{-}$and $[2 \mathrm{M}-\mathrm{H}]^{-}$ions in their negative ion mass spectra. The [M $-\mathrm{H}]^{-}$were selected for CID fragmentation to produce MS/MS spectra. The prominent MS/MS ions were selected for further $\mathrm{MS}^{\mathrm{n}}$ analysis ( $n=3$ to 4 ). The collision energy ranged from 30 to $50 \%$.

The compounds could be classified into five groups according to their chemical structures and fragmentation patterns. The dominant fragmentation pathways of the compounds studied are losses of $\mathrm{H}_{2} \mathrm{O}$ and $\mathrm{CO}_{2}$; however, the cleavages of C-ring and D-ring, which

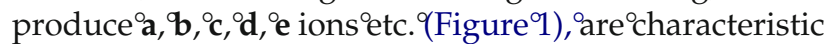
features. The major fragmentation pathways are given in Scheme 1.

Fragmentation of Ganoderic Acid A and Ganoderic Acid $\mathrm{C}_{2}$ (Type I)

When applied to an collision energy of $40 \%$, the [M $\mathrm{H}]^{-\circ}$ ion $^{\circ}$ at $^{\circ} \mathrm{m} / \mathrm{z} 515^{\circ}$ of $^{\circ}$ ganoderic $^{\circ}$ acid $^{\circ} \mathrm{A}^{\circ}$ (Figure ${ }^{\circ} 2 \mathrm{a}$ ) 

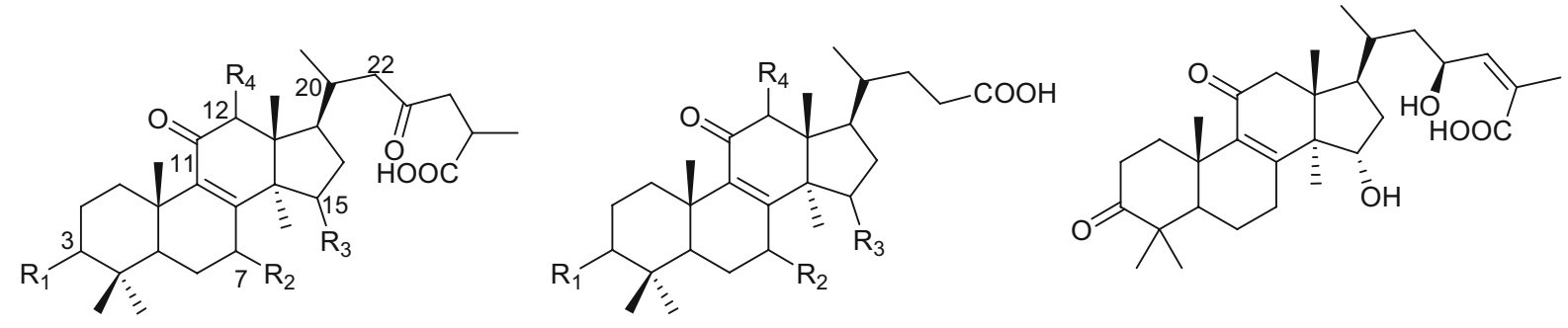

A

B

\begin{tabular}{|c|c|c|c|c|c|c|c|c|}
\hline No. & Compound name & Type & $\mathrm{R}_{1}$ & $\mathrm{R}_{2}$ & $\mathrm{R}_{3}$ & $\mathrm{R}_{4}$ & $\begin{array}{c}\text { Double } \\
\text { bond }\end{array}$ & MW \\
\hline 1 & 12-hydroxyganoderic acid $\mathrm{C}_{2}$ & A & $\beta-\mathrm{OH}$ & $\beta-\mathrm{OH}$ & $\alpha-\mathrm{OH}$ & $\overline{\mathrm{OH}}$ & - & 534 \\
\hline 2 & Ganoderic acid $\mathrm{C}_{2}$ & A & $\beta-\mathrm{OH}$ & $\beta-\mathrm{OH}$ & $\alpha-\mathrm{OH}$ & $\mathrm{H}$ & - & 518 \\
\hline 3 & Ganolucidic acid B & A & $\beta-\mathrm{OH}$ & $\mathrm{H}$ & $\alpha-\mathrm{OH}$ & $\mathrm{H}$ & - & 502 \\
\hline 4 & Lucidenic acid $\mathrm{N}$ & $\mathrm{B}$ & $\beta-\mathrm{OH}$ & $\beta-\mathrm{OH}$ & $=\mathrm{O}$ & $\mathrm{H}$ & - & 460 \\
\hline 5 & Ganoderic acid $\mathrm{C}_{6}$ & A & $\beta-\mathrm{OH}$ & $=\mathrm{O}$ & $=\mathrm{O}$ & $\beta-\mathrm{OH}$ & - & 530 \\
\hline 6 & $\begin{array}{l}\text { 3?-hydroxy-4,4,14-trimethyl-7,11,15-trioxochol- } \\
\text { 8-en-24-oic acid }\end{array}$ & $\mathrm{B}$ & $\beta-\mathrm{OH}$ & $=\mathrm{O}$ & $=\mathrm{O}$ & $\mathrm{H}$ & - & 458 \\
\hline 7 & Ganoderic acid $\mathrm{G}$ & A & $\beta-\mathrm{OH}$ & $\beta-\mathrm{OH}$ & $=\mathrm{O}$ & $\beta-\mathrm{OH}$ & - & 532 \\
\hline 8 & Ganoderenic acid B & A & $\beta-\mathrm{OH}$ & $\beta-\mathrm{OH}$ & $=\mathrm{O}$ & $\mathrm{H}$ & $\Delta_{20,22}$ & 514 \\
\hline 9 & Ganoderic acid B & $\mathrm{A}$ & $\beta-\mathrm{OH}$ & $\beta-\mathrm{OH}$ & $=\mathrm{O}$ & $\mathrm{H}$ & - & 516 \\
\hline 10 & Lucidenic acid E & B & $\beta-\mathrm{OH}$ & $=\mathrm{O}$ & $=\mathrm{O}$ & $\beta-\mathrm{OAc}$ & - & 516 \\
\hline 11 & Ganoderic acid $\mathrm{AM}_{1}$ & A & $\beta-\mathrm{OH}$ & $=\mathrm{O}$ & $=\mathrm{O}$ & $\mathrm{H}$ & - & 514 \\
\hline 12 & Ganoderenic acid $\mathrm{K}$ & A & $\beta-\mathrm{OH}$ & $\beta-\mathrm{OH}$ & $=\mathrm{O}$ & $\beta-\mathrm{OAc}$ & $\Delta_{20,22}$ & 572 \\
\hline 13 & Ganoderic acid $\mathrm{K}$ & A & $\beta-\mathrm{OH}$ & $\beta-\mathrm{OH}$ & $=\mathrm{O}$ & $\beta-\mathrm{OAc}$ & - & 574 \\
\hline 14 & $\begin{array}{l}\text { 7,15-dihydroxy-4,4,14-trimethyl-3,11-dioxochol- } \\
\text { 8-en-24-oic acid }\end{array}$ & B & $=\mathrm{O}$ & $\mathrm{OH}$ & $\mathrm{OH}$ & $\mathrm{H}$ & - & 460 \\
\hline 15 & Elfvingic acid $\mathrm{A}$ & A & $=\mathrm{O}$ & $=\mathrm{O}$ & $\beta-\mathrm{OH}$ & $\alpha-\mathrm{OH}$ & $\Delta_{20,22}$ & 528 \\
\hline 16 & Ganoderic acid A & A & $=\mathrm{O}$ & $\beta-\mathrm{OH}$ & $\alpha-\mathrm{OH}$ & $\mathrm{H}$ & - & 516 \\
\hline 17 & Ganoderic acid $\mathrm{H}$ & A & $\beta-\mathrm{OH}$ & $=\mathrm{O}$ & $=\mathrm{O}$ & $\beta-\mathrm{OAc}$ & - & 572 \\
\hline 18 & $\begin{array}{l}\text { 12,15-bis(acetyloxy)-3-hydroxy-7,11,23-trioxo- } \\
\text { lanost-8-en-26-oic acid }\end{array}$ & A & $\mathrm{OH}$ & $=\mathrm{O}$ & OAc & OAc & - & 616 \\
\hline 19 & Ganolucidic acid A & A & $=\mathrm{O}$ & $\mathrm{H}$ & $\alpha-\mathrm{OH}$ & $\mathrm{H}$ & - & 500 \\
\hline 20 & $\begin{array}{l}\text { 12-hydroxy-3,7,11,15,23-pentaoxo-lanost-8-en- } \\
26 \text {-oic acid }\end{array}$ & A & $=\mathrm{O}$ & $=\mathrm{O}$ & $=\mathrm{O}$ & $\mathrm{OH}$ & - & 528 \\
\hline 21 & Lucidenic acid A & B & $=\mathrm{O}$ & $\beta-\mathrm{OH}$ & $=\mathrm{O}$ & $\mathrm{H}$ & - & 458 \\
\hline 22 & 12-hydroxyganoderic acid D & A & $=\mathrm{O}$ & $\beta-\mathrm{OH}$ & $=\mathrm{O}$ & $\mathrm{OH}$ & - & 530 \\
\hline 23 & Ganoderenic acid D & A & $=\mathrm{O}$ & $\beta-\mathrm{OH}$ & $=\mathrm{O}$ & $\mathrm{H}$ & $\Delta_{20,22}$ & 512 \\
\hline 24 & Lucidenic acid $\mathrm{F}$ & $\mathrm{B}$ & $=\mathrm{O}$ & $=\mathrm{O}$ & $=\mathrm{O}$ & $\mathrm{H}$ & - & 456 \\
\hline 25 & Ganoderic acid D & A & $=\mathrm{O}$ & $\beta-\mathrm{OH}$ & $=\mathrm{O}$ & $\mathrm{H}$ & - & 514 \\
\hline 26 & Lucidenic acid D & B & $=\mathrm{O}$ & $=\mathrm{O}$ & $=\mathrm{O}$ & $\beta-\mathrm{OAc}$ & - & 514 \\
\hline 27 & Ganoderic acid F & A & $=\mathrm{O}$ & $=\mathrm{O}$ & $=\mathrm{O}$ & $\mathrm{H}$ & - & 512 \\
\hline 28 & 12-acetoxyganoderic acid D & A & $=\mathrm{O}$ & $\beta-\mathrm{OH}$ & $=\mathrm{O}$ & OAc & - & 572 \\
\hline 29 & 3-acetylganoderic acid $\mathrm{H}$ & A & $\beta-\mathrm{OAc}$ & $=\mathrm{O}$ & $=\mathrm{O}$ & $\beta-\mathrm{OAc}$ & - & 614 \\
\hline 30 & Ganolucidic acid D & $\mathrm{C}$ & - & - & - & - & - & 500 \\
\hline 31 & 12-acetoxyganoderic acid $\mathrm{F}$ & A & $=\mathrm{O}$ & $=\mathrm{O}$ & $=\mathrm{O}$ & $\beta-\mathrm{OAc}$ & - & 570 \\
\hline 32 & Ganoderic acid $\mathrm{J}$ & A & $=\mathrm{O}$ & $=\mathrm{O}$ & $\alpha-\mathrm{OH}$ & $\mathrm{H}$ & - & 514 \\
\hline
\end{tabular}
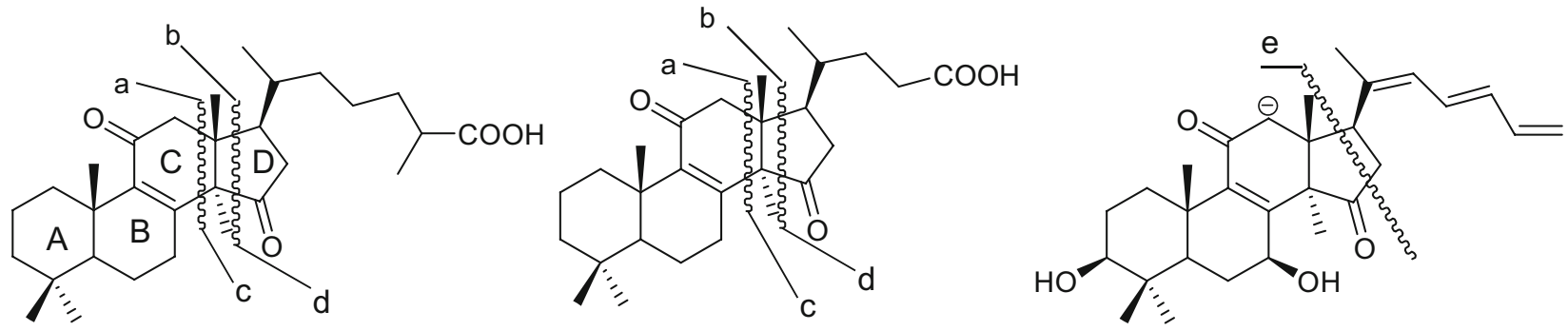

Figure 1. Chemical structures of the triterpenoids identified from Ganoderma lucidum and the characteristic fragmentation pathways of triterpenic acids. 


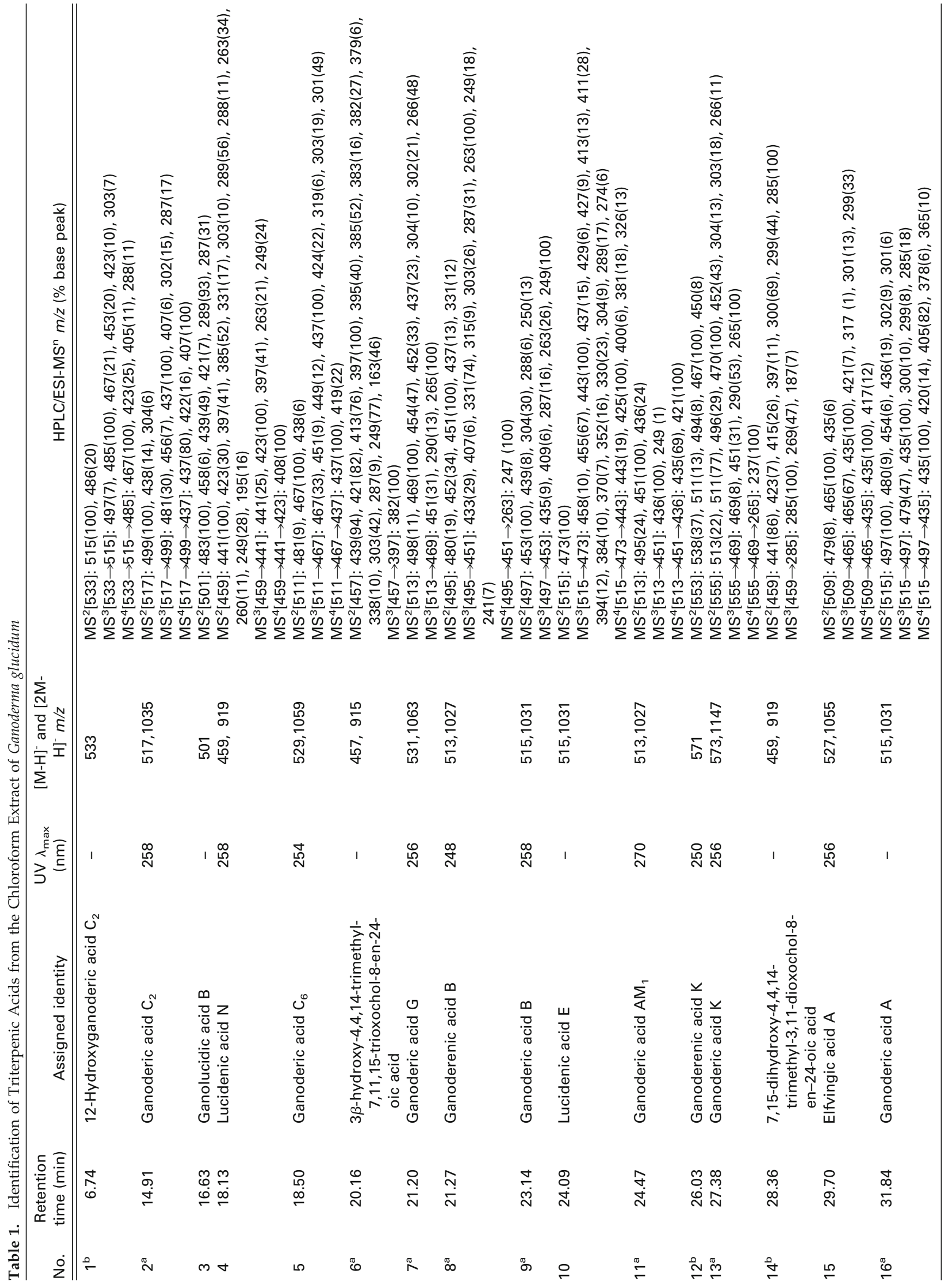




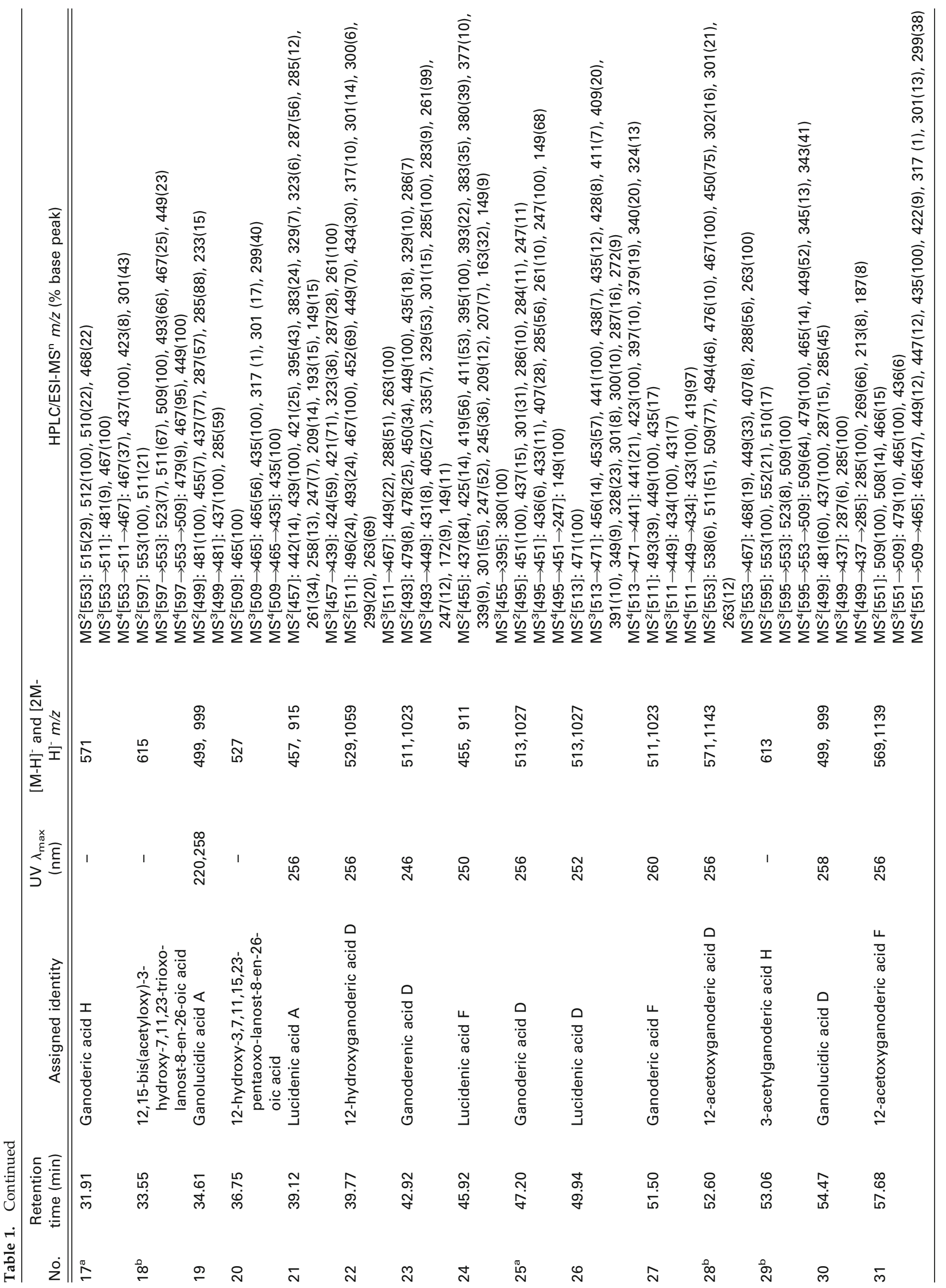


produced a prominent ion at $\mathrm{m} / \mathrm{z} 497$ by eliminating a molecule of $\mathrm{H}_{2} \mathrm{O}(\Delta \mathrm{m}=18)$. The $\mathrm{m} / \mathrm{z} 497$ ion was further subjected to $\mathrm{MS}^{3}$ analysis to produce signals at $\mathrm{m} / \mathrm{z} 479$ and 435 , formed by the sequential losses of $\mathrm{H}_{2} \mathrm{O}$ and carbon dioxide $\left(\mathrm{CO}_{2}, \Delta \mathrm{m}=44\right)$ through a rearrangement process at the side chain, as suggested in Scheme 1. The $\mathrm{m} / \mathrm{z}$ ion 435 then underwent successive losses of $\mathrm{CH}_{3}(\Delta \mathrm{m}=15)$ to generate an ion at $m / z 405$. The above product ions were the dominant fragments of ganoderic acid A; moreover, some minor signals at $\mathrm{m} / \mathrm{z} 285$ (b 16), $301(\mathbf{b}), 300(\mathbf{b}-1)$, and $299(\mathbf{b}-2)$ were also observed in $\mathrm{MS}^{\mathrm{n}}(n=2$ to 3 ) spectra, especially in the $\mathrm{MS}^{3^{\circ}}$ spectrum (Figure 3 ). We assumed that the fragmentation ${ }^{\circ}$ Should ${ }^{\circ}$ result ${ }^{\circ}$ from ${ }^{\circ}$ cleavage $^{\circ}$ of ${ }^{\circ}$ the ${ }^{\circ}$ D-ring ${ }^{\circ}$ (Figure 1), ${ }^{\circ}$ and $^{\circ}$ this $^{\circ}$ provided $^{\circ}$ characteristic $^{\circ}$ information ${ }^{\circ}$ for compounds with skeletons such as that of ganoderic acid A. The fragmentation pathway is depicted in Scheme 1.

Ganoderic acid $C_{2}$ gave similar ESI-MS ${ }^{\mathrm{n}}$ ( $n=1$ to 4 ) spectra to those of ganoderic acid A, except that the corresponding ions were heavier by $2 \mathrm{Da}$, which resulted from the difference of the group at C-3. Hence, it could be concluded that different groups at C-3 do not change the main fragmentation pathway of the compounds investigated.

Fragmentation of Ganoderic Acid $A M_{1}$ and Ganoderic Acid J (Type II)

Ganoderic acid $\mathrm{AM}_{1}$ gave the $[\mathrm{M}-\mathrm{H}]^{-}$ion at $m / z 513$, which produced ions at $\mathrm{m} / \mathrm{z} 495$ and 451 in the MS/MS spectrum, originating from neutral loss of $\mathrm{H}_{2} \mathrm{O}$ and $\mathrm{CO}_{2}$ similar to the results of ganoderic acid $\mathrm{A}$; but ions involving cleavage of the rings were hardly observed; the very minor a +2 ion at $\mathrm{m} / \mathrm{z} 249$ indicated a characteristic rearrangement in the process of cleavage of the rings for the structures with 7-carbonyl (see Scheme 1). $\mathrm{MS}^{3}$ and $\mathrm{MS}^{4}$ spectra of ganoderic acid $\mathrm{AM}_{1}$ yielded abundant product ions at $\mathrm{m} / \mathrm{z} 436$ and 421 respectively, through loss of $\mathrm{CH}_{3}(\Delta \mathrm{m}=15)$.

The fragmentation behavior of ganoderic acid $\mathrm{AM}_{1}$ could be applied to ganoderic acid J. The $[\mathrm{M}-\mathrm{H}]^{-}$ion at $\mathrm{m} / \mathrm{z} 513$ gave a prominent product ion at $\mathrm{m} / \mathrm{z} 451$; the $\mathrm{MS}^{3}$ spectrum of the $m / z 451$ ion was somewhat different from that of ganoderic acid $\mathrm{AM}_{1}$; it gave two abundant $^{\circ}$ ions $^{\circ}$ at ${ }^{\circ} \mathrm{m} / \mathrm{z} 436^{\circ}$ and $^{\circ} 421^{\circ}$ (Figure ${ }^{\circ} 4$ ). ${ }^{\circ}$ We suggested that this might be due to the different substitute at C-15. In such a case, loss of a molecule of $\mathrm{H}_{2} \mathrm{O}$ could be observed in the $\mathrm{MS}^{4}$ spectrum.

Fragmentation of Ganoderic Acid B, D, G, K, and Ganoderenic Acid B (Type III)

The fragmentation behavior of ganoderic acid B were very different from those of compounds of types I and II. In its full scan MS spectrum, the prominent signal was not the $[\mathrm{M}-\mathrm{H}]^{-}$ion at $m / z 515$ but the $[\mathrm{M}-\mathrm{H}-$ $\mathrm{H}_{2} \mathrm{O}^{-{ }^{\circ}}$ ion $^{\circ}$ at $^{\circ} \mathrm{m} / \mathrm{z} 497^{\circ}\left(\right.$ Figure $^{\circ} 2 \mathrm{~b}$ ), ${ }^{\circ}$ resulting ${ }^{\circ}$ from $^{\circ}{ }^{a}$ 
Ganoderic acid A
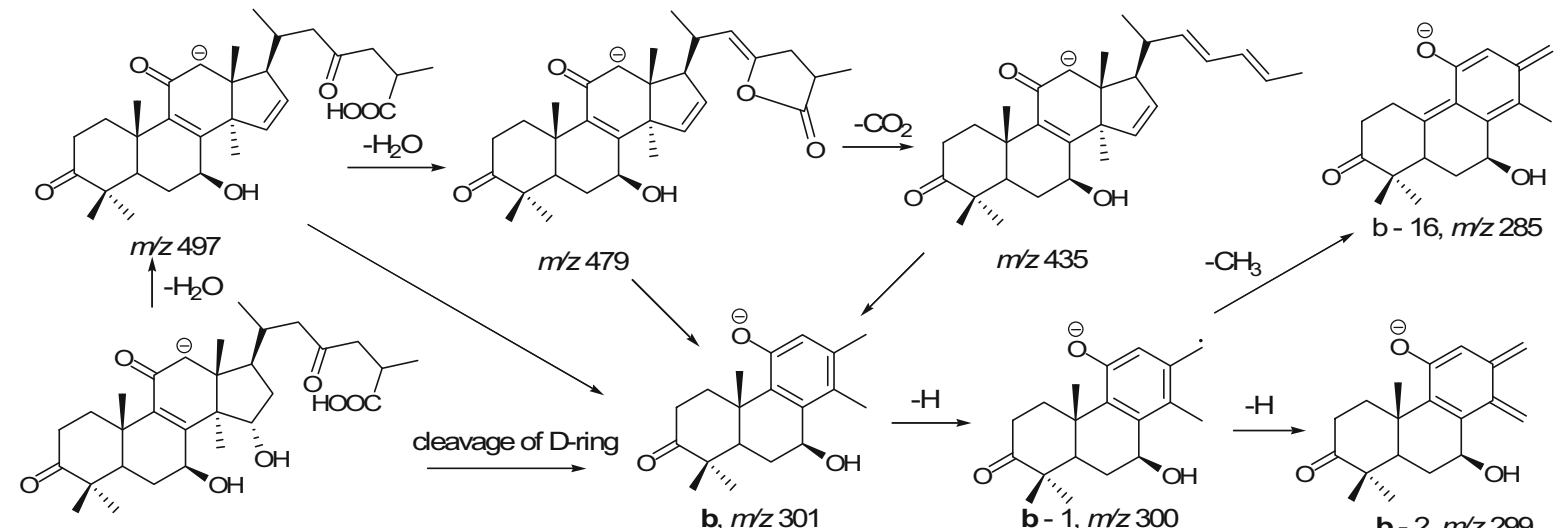

ganoderic acid $\mathrm{A},\left[\mathrm{M}-\mathrm{H}^{-}\right.$,

"m/z 435

$b-16, m / z 285$

$m / z 515$

Ganoderic acid $\mathrm{AM}_{1}$

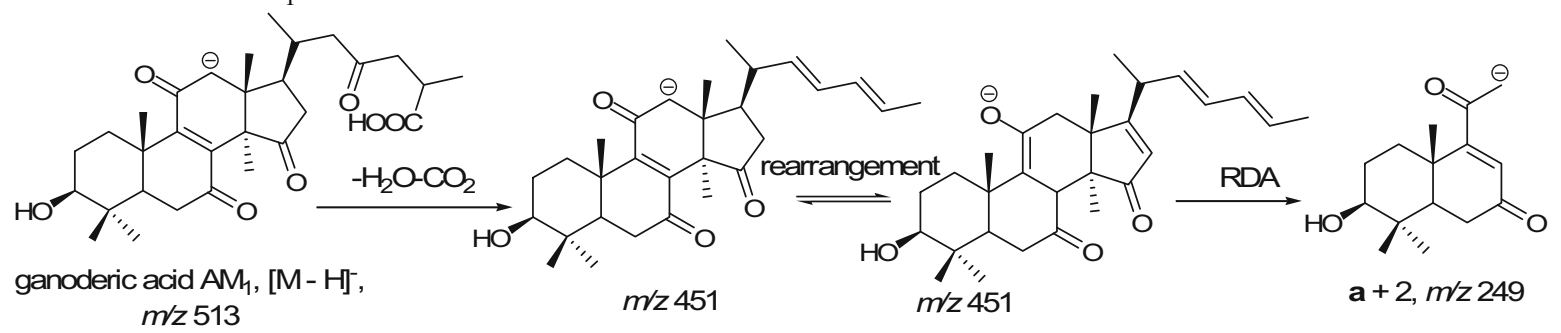

Ganoderic acid B

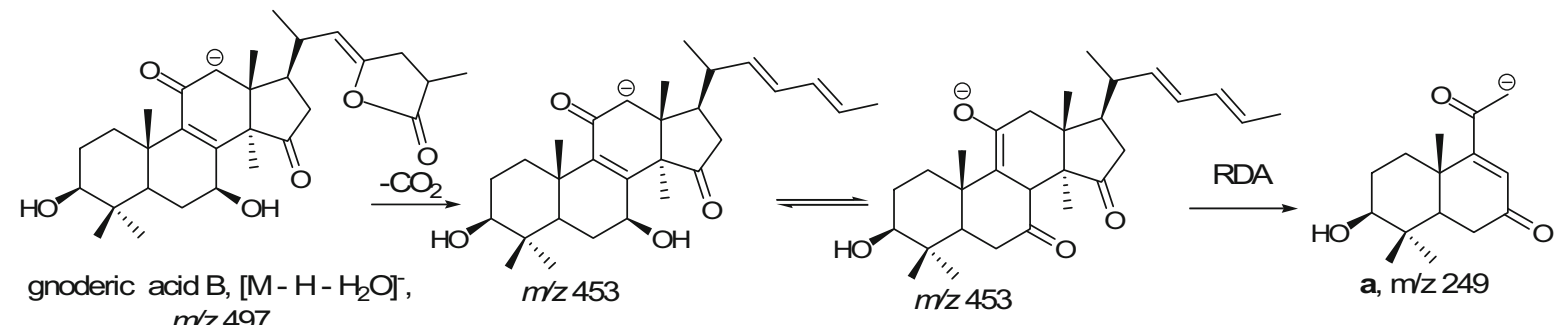

Ganoderenic acid B

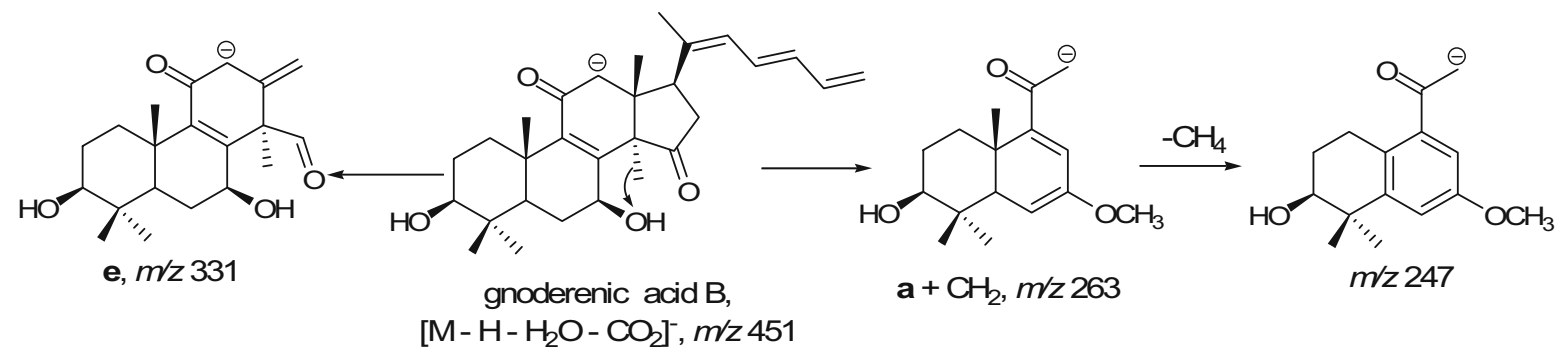

Ganoderic acid $\mathrm{H}$

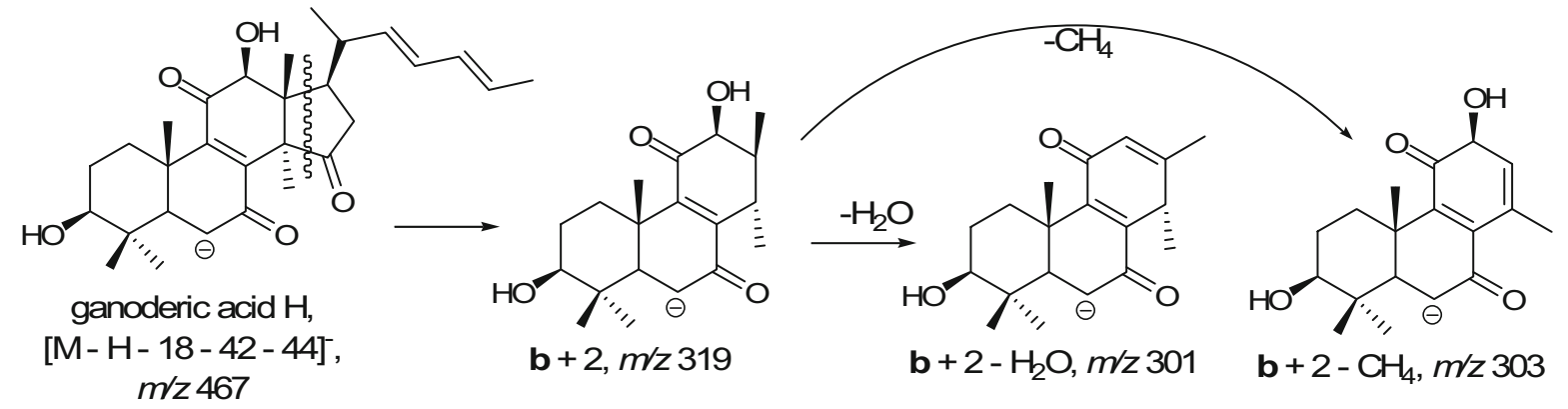

Scheme 1. Major fragmentation pathways of some triterpenoids. 

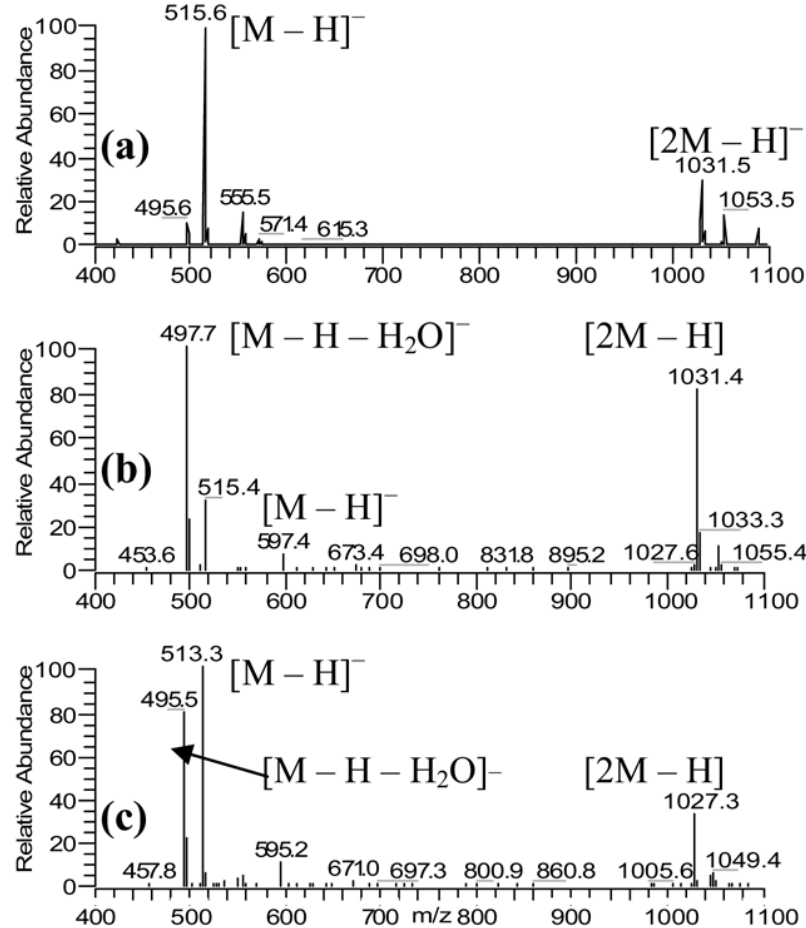

Figure 2. Full scan MS spectra for ganoderic acid A (a), ganoderic acid B (b), and ganoderenic acid B (c).

rearrangement process at the side chain, as suggested in Scheme 1. We assumed that this was the characteristic fragmentation feature for structures with 15-hydroxy7-oxo groups. The $\mathrm{m} / \mathrm{z} 497$ ion was then subjected to MS/MS analysis and produced a prominent ion at $\mathrm{m} / \mathrm{z}$ 453 , formed by loss of a molecule of $\mathrm{CO}_{2}(\Delta \mathrm{m}=44)$. Figure ${ }^{\circ} 4 \mathrm{~d}^{\circ}$ shows ${ }^{\circ}$ the ${ }^{\circ} \mathrm{MS}^{3^{\circ}}$ spectrum ${ }^{\circ}$ of ${ }^{\circ}$ the ${ }^{\circ} \mathrm{m} / \mathrm{z} 453^{\circ}$ ion; the most prominent product ion was at $\mathrm{m} / \mathrm{z} 249$ (a), followed by the $\mathbf{a}+\mathrm{CH}_{2}$ ion at $m / z 263$ along with $\mathbf{b}-$ $\mathrm{H}-\mathrm{CH}_{3}$ ion at $\mathrm{m} / \mathrm{z} 287$, corresponding to rearrangement and cleavage of the C- and D-rings, respectively (see Scheme 1).

All issues discussed above for ganoderic acid B could apply here for other compounds of type III. Ganoderic acid D had almost identical ESI-MS ${ }^{n}(n=1$ to 4$)$ spectra with those of ganoderic acid B, except that the corresponding ions were lighter by two mass units, resulting from the different substitution at C-3. Ganoderic acid G was a monohydroxylated derivative at C-12 of ganoderic acid $\mathrm{B}$ and, thus, all its corresponding ions (a ion at $m / z 265$, b ion at $m / z 319$ ) were heavier by 16 Da than those of ganoderic acid B. Ganoderic acid K was a acetylated derivative at $\mathrm{C}-12$ of ganoderic acid $\mathrm{G}$ and its $\left[\mathrm{M}-\mathrm{H}-\mathrm{H}_{2} \mathrm{O}\right]^{-}$ion at $\mathrm{m} / \mathrm{z} 555$ yielded an ion in the MS/MS spectrum at $m / z 513$, originating from a neutral loss of $42 \mathrm{Da}\left(\mathrm{CH}_{2}=\mathrm{CO}\right)$. We assumed that this reaction involved the elimination of the acetyl at C-12. The obtained ion then showed the same fragmentation patterns as those of ganoderic acid G. Some characteristic $^{\circ}$ signals ${ }^{\circ}$ were $^{\circ}$ shown $^{\circ}$ in $^{\circ}$ Table $^{\circ} 2$.

The mass spectrum of ganoderenic acid B was some- what different from that of ganoderic acid B. Its full scan MS spectrum gave both $[\mathrm{M}-\mathrm{H}]^{-}$ion $(\mathrm{m} / \mathrm{z} 513)$ and $\left[\mathrm{M}-\mathrm{H}-\mathrm{H}_{2} \mathrm{O}\right]^{-}$ion $(\mathrm{m} / \mathrm{z} 495)$ in abundant signals (Figure 2c). ${ }^{\circ} \mathrm{We}^{\circ}$ suggested ${ }^{\circ}$ that ${ }^{\circ}$ this $^{\circ}$ character $^{\circ}$ could $^{\circ}$ be applied ${ }^{\circ}$ for $^{\circ}$ all $^{\circ}{ }^{\circ}$ ther ${ }^{\circ}$ ganoderenic ${ }^{\circ}$ acids. ${ }^{\circ}$ The ${ }^{\circ}[\mathrm{M}-\mathrm{H}-$ $\left.\mathrm{H}_{2} \mathrm{O}\right]^{-}$ion at $\mathrm{m} / \mathrm{z} 495$ showed similar fragmentation patterns ${ }^{\circ}$ to ${ }^{\circ}$ those ${ }^{\circ}$ of $^{\circ}$ ganoderic $^{\circ}$ acid $^{\circ} \mathrm{B},{ }^{\circ}$ but ${ }^{\circ}$ the ${ }^{\circ}$ abundances of some ions were very different. The $\mathbf{a}+\mathrm{CH}_{2}$ ion $(\mathrm{m} / \mathrm{z} 263)$ was a base peak in the $\mathrm{MS}^{3}$ spectrum, followed ${ }^{\circ}$ by ${ }^{\circ}$ e ion ${ }^{\circ}$ at $^{\circ} \mathrm{m} / z 331^{\circ}$ (see Figure $^{\circ} 1^{\circ}$ and ${ }^{\circ}$ Scheme 1), along with $\mathbf{b}-\mathrm{H}-\mathrm{CH}_{3}$ ion at $\mathrm{m} / \mathrm{z} 287$; the $\mathbf{a}$ ion at $\mathrm{m} / \mathrm{z}$ 249 was less abundant on the contrary to that of ganoderic acid B.

\section{Fragmentation of Ganoderic Acid H (Type IV)}

Ganoderic acid $\mathrm{H}$ was an acetoxylated derivative at C-12 of ganoderic acid $\mathrm{AM}_{1}$, but its fragmentation behavior was somewhat different from those of ganoderic acid $\mathrm{AM}_{1}$. The most prominent ion in its full scan mass spectrum was the $\left[\mathrm{M}-\mathrm{H}-\mathrm{H}_{2} \mathrm{O}\right]^{-}$ion at $m / z 553$ like that of ganoderic acid $\mathrm{K}$. Neutral losses of $\mathrm{CH}_{2}=$ $\mathrm{CO}(\Delta \mathrm{m}=42, \mathrm{~m} / \mathrm{z} 553 \rightarrow 511)$, and $\mathrm{CO}_{2}(\Delta \mathrm{m}=44, \mathrm{~m} / \mathrm{z}$ $511 \rightarrow 467)$ were observed in the $\mathrm{MS}^{2}$ and $\mathrm{MS}^{3}$ spectra, respectively. The obtained $\mathrm{m} / \mathrm{z} 467$ ion then gave abundant signals at $\mathrm{m} / \mathrm{z} 301$ and 303 in the MS ${ }^{4}$ spectrum along with the base peak at $m / z 437$. We assumed that the two ions should be $\mathbf{b}+2-\mathrm{H}_{2} \mathrm{O}$ and $\mathbf{b}+2-\mathrm{H}-\mathrm{CH}_{3}$ ions $^{\circ}\left(\right.$ Figure $\left.^{\circ} \mathrm{c}\right)$, involving the ${ }^{9}$ transfer ${ }^{\circ}$ of $^{\circ}$ two ${ }^{\circ}$ hydrogen atoms from part $\mathbf{d}$ to part $\mathbf{b}$ in the process of cleavage of the D-ring (Scheme 1); this could be the characteristic feature for structures with 12-hydroxy-7-oxo groups.

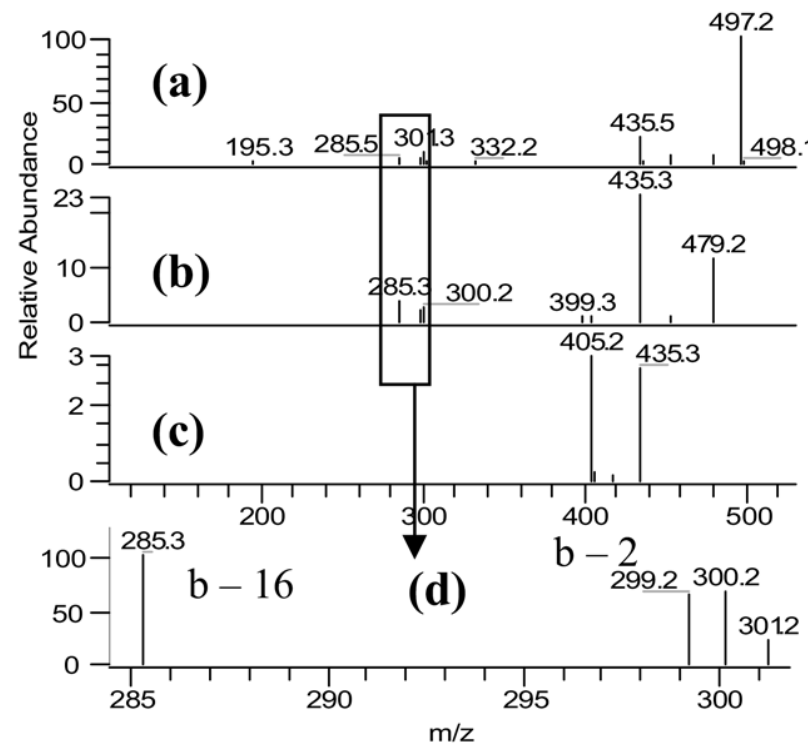

Figure 3. ESI-MS spectra for ganoderic acid A: (a) MS/MS spectrum of $[\mathrm{M}-\mathrm{H}]^{-}$ion at $\mathrm{m} / \mathrm{z} 515 ;$ (b) $\mathrm{MS}^{3}$ spectrum of $\mathrm{m} / \mathrm{z} 497$ $(515 \rightarrow 497) ;$ (c) MS ${ }^{4}$ spectrum of $m / z 435(515 \rightarrow 497 \rightarrow 435)$; (d) the box zoomed in for $\mathbf{b}, \mathbf{b}-1, \mathbf{b}-2$ and, $\mathbf{b}-16$ ions. 

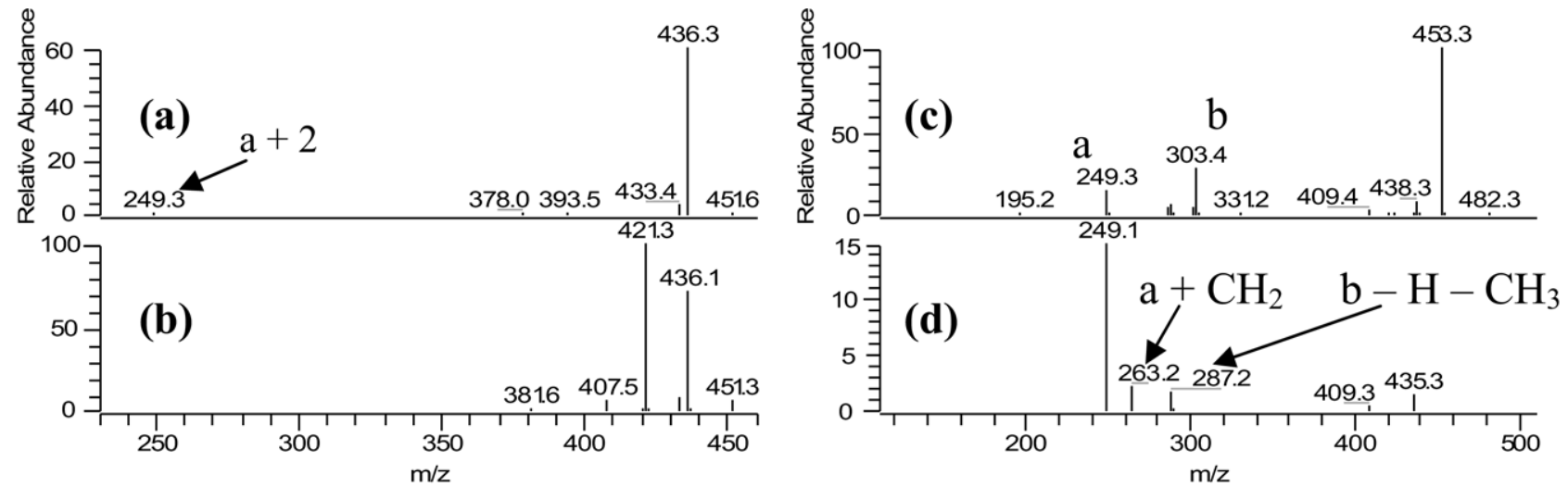

Figure 4. ESI-MS spectra for ganoderic acids: $\mathrm{MS}^{3}$ spectra for ion at $m / z 451$ of ganoderic acid $\mathrm{AM}_{1}$ (a) and ganoderic acid J (b); MS/MS spectrum at $\mathrm{m} / \mathrm{z} 497$ (c) and $\mathrm{MS}^{3}$ spectrum at $\mathrm{m} / \mathrm{z} 453$ (d) of ganoderic acid $\mathrm{B}$.

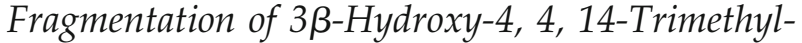
7, 11, 15-Trioxochol-8-en-24-oic Acid (Type V)

The structure of this type of compound has a skeleton of lanostane containing 27 carbon atoms and is called lucidenic acid. Part of the structure is similar to that of ganoderic acid except the side chain at C-17. Thus, some characteristic fragmentation features of ganoderic acid could be applied for lucidenic acid.

Figure ${ }^{\circ} 5 \mathrm{~d}^{\circ}$ shows $^{\circ}$ the ${ }^{\circ} \mathrm{MS} / \mathrm{MS}^{\circ}$ spectrum $^{\circ}$ of ${ }^{\circ}$ the ${ }^{\circ}\left[\mathrm{M}^{\circ}-\right.$ $\mathrm{H}]^{-}$ion at $m / z 457$ for $3 \beta$-hydroxy-4, 4, 14-trimethyl-7,

Table 2. Characteristic ESI-MS spectral information for Type III triterpenoids

\begin{tabular}{|c|c|c|c|c|c|c|c|}
\hline \multirow[b]{2}{*}{ No. } & \multicolumn{2}{|c|}{ Full scan $(m / z, \%)$} & \multirow[b]{2}{*}{ a } & \multirow[b]{2}{*}{$a+14$} & \multirow[b]{2}{*}{$\mathrm{b}$} & \multirow[b]{2}{*}{$b-16$} & \multirow[b]{2}{*}{$b-29$} \\
\hline & {$[\mathrm{M}-\mathrm{H}]^{-}$} & {$\left[\mathrm{M}-\mathrm{H}-\mathrm{H}_{2} \mathrm{O}\right]^{-}$} & & & & & \\
\hline 7 & $531(7)$ & $513(100)$ & 265 & & 319 & 303 & 290 \\
\hline 8 & $513(100)$ & $495(80)$ & 249 & 263 & 303 & 287 & \\
\hline 9 & $515(25)$ & $497(100)$ & 249 & 263 & 303 & 287 & \\
\hline 12 & $571(86)$ & $553(100)$ & 265 & & & 303 & 290 \\
\hline 13 & $573(15)$ & $555(100)$ & 265 & & & 303 & 290 \\
\hline 22 & $529(7)$ & $511(100)$ & 263 & & 317 & 301 & 288 \\
\hline 23 & $511(80)$ & $493(100)$ & 247 & 261 & 301 & 285 & \\
\hline 25 & $513(20)$ & 495 (100) & 247 & 261 & 301 & 285 & \\
\hline 28 & $571(1)$ & $553(100)$ & 263 & & & 301 & 288 \\
\hline
\end{tabular}
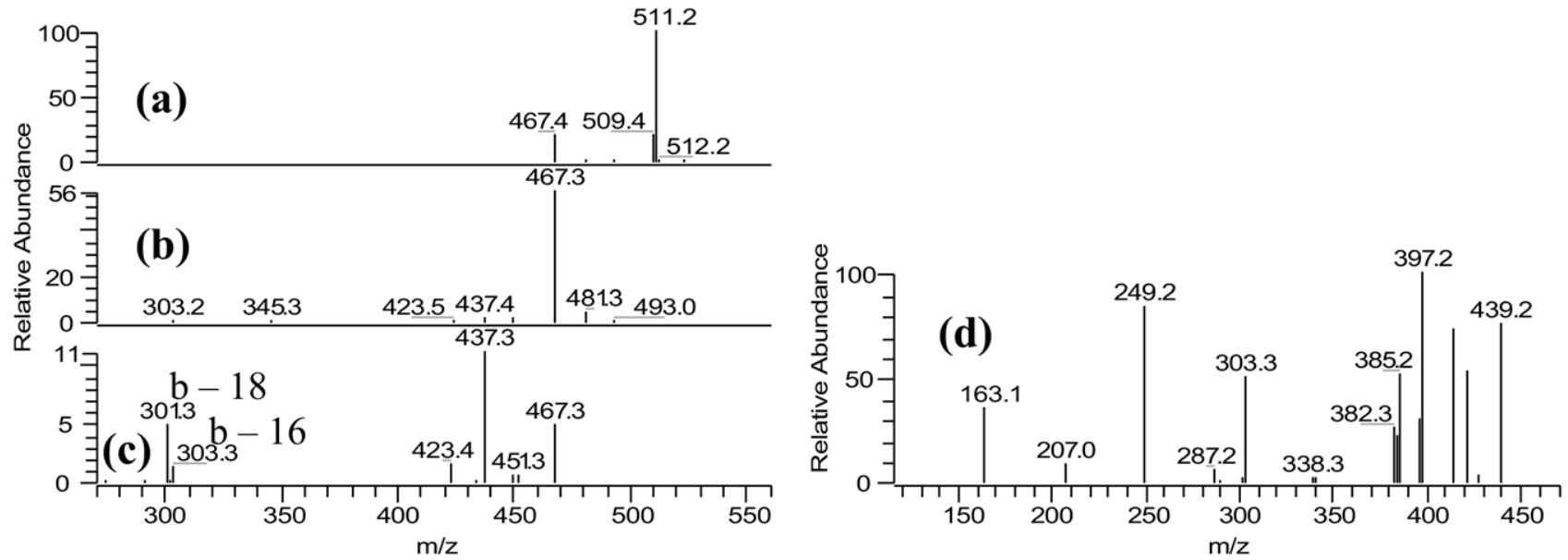

Figure 5. ESI-MS spectra for ganoderic acid $\mathrm{H}$ : (a) MS/MS spectrum of $\left[\mathrm{M}-\mathrm{H}-\mathrm{H}_{2} \mathrm{O}\right]^{-}$ion at $m / z$ 553; (b) MS ${ }^{3}$ spectrum of $m / z 511(553 \rightarrow 511)$; (c) MS ${ }^{4}$ spectrum of $m / z 467(553 \rightarrow 511 \rightarrow 467)$; (d) MS $/$ MS spectrum of $[\mathrm{M}-\mathrm{H}]^{-}$ion at $\mathrm{m} / \mathrm{z} 457$ for $3 \beta$-hydroxy-4, 4, 14-trimethyl-7, 11, 15-trioxochol-8-en-24-oic acid. 


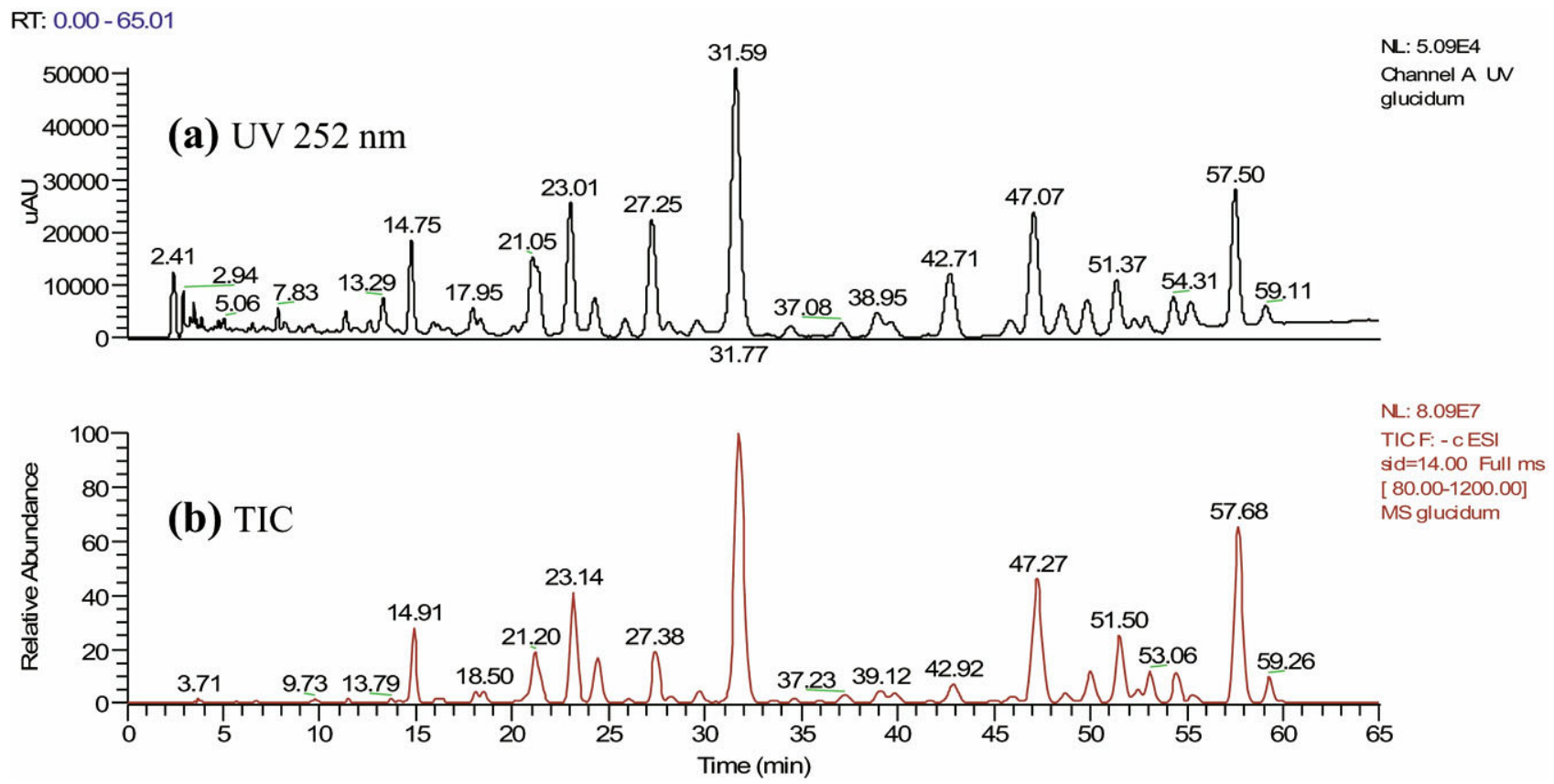

Figure 6. HPLC-DAD-ESI-MS ${ }^{\mathrm{n}}$ analysis of the $\mathrm{CHCl}_{3}$ extract of Ganoderma lucidum. (a) HPLC-UV chromatogram monitored at $252 \mathrm{~nm}$. (b) LC-negative ion ESI-MS total ion current (TIC) profile.

11, 15-trioxochol-8-en-24-oic acid. The most prominent ion was $\mathrm{m} / \mathrm{z} 397$, originating from loss of a molecule of acetic acid $\left(\mathrm{CH}_{3} \mathrm{COOH}, \Delta \mathrm{m}=60\right)$ through the $\beta$ cleavage of the carboxy group. In addition, $[\mathrm{M}-\mathrm{H}-$ $\left.\mathrm{H}_{2} \mathrm{O}\right]^{-}(m / z 439),\left[\mathrm{M}-\mathrm{H}-2 \mathrm{H}_{2} \mathrm{O}\right]^{-}(m / z 421)$, and [M - $\mathrm{H}$ $\left.-\mathrm{CO}_{2}\right]^{-}(\mathrm{m} / \mathrm{z} 413)$ ions were also observed. The appearance of $\mathbf{a}+2(\mathrm{~m} / \mathrm{z} 249)$ and $\mathbf{b}+2(\mathrm{~m} / \mathrm{z} 303)$ ions demonstrated characteristic fragmentation feature for structures with 7-carbonyl.

\section{HPLC-DAD-ESI-MS ${ }^{n}$ Analysis of the Crude Extract of Ganoderma lucidum}

Figure ${ }^{\circ}{ }^{\circ}$ shows ${ }^{\circ}$ the ${ }^{\circ} H P L C-U^{\circ}{ }^{\circ} d^{\circ} T^{\circ} C^{\circ}$ profiles $^{\circ}$ of the extract of Ganoderma lucidum. To obtain optimal extraction efficiency and good separation, we optimized the extraction and chromatographic conditions [34]..$^{\circ}$ Chloroform, ${ }^{\circ}$ methanol, ${ }^{\circ}$ and $^{\circ}$ chloroform-methanol solutions were attempted as the extraction solvent. At last, chloroform was chosen as the extraction solvent since the triterpenoids could not only efficiently be extracted but also well resolved from background. Ultrasonic extraction was compared with refluxing. It was found that both extraction methods have the similar extraction efficiency but ultrasonic extraction was simpler, hence the ultrasonic bath extraction was chosen as the preferred method.

Different mobile phase compositions were optimized and acetic acid was added in the mobile phase to obtain desired separation and acceptable tailing factor. As a result, acetonitrile and water containing $0.2 \%$ acetic acid was chosen as the eluting solvent system. The UV detector was monitored at $252 \mathrm{~nm}$ to make sure that all triterpenoids gave good responses.

A total of 32 triterpenoids were characterized from the ${ }^{\circ}$ Chloroform ${ }^{\circ}$ extract $^{\circ}$ of $^{\circ} G_{\text {. lucidum }}$ (Table ${ }^{\circ} 1$ ), ${ }^{\circ}$ and ${ }^{\circ} 11$ of them were unambiguously identified by comparing their retention times and mass spectra with those of reference standards. For unknown peaks, the structures were tentatively established on the base of their ESI-MS and $\mathrm{MS}^{\mathrm{n}}$ ( $n=2$ to 4 ) spectra, according to the general fragmentation rules of triterpenoids summarized above.

\section{Identification of Type I Triterpenoids}

In addition to ganoderic acid $\mathrm{A}\left(\mathrm{t}_{\mathrm{R}}=31.84 \mathrm{~min}, 16\right)$ and $\mathrm{C}_{2^{\circ}}\left(\mathrm{t}_{\mathrm{R}^{\circ}}={ }^{\circ} 14.91^{\circ} \mathrm{min},{ }^{\circ}\right)$, ${ }^{\circ}$ another ${ }^{\circ}$ peak $^{\circ}{ }^{\circ}{ }^{\circ} 6.74^{\circ} \mathrm{min}^{\circ}$ (Table $1,{ }^{\circ}$ Compound $\left.{ }^{\circ} \mathbf{1}\right)^{\circ}$ was $^{\circ}$ plausibly ${ }^{\circ}$ identified. ${ }^{\circ} \mathrm{A}^{\circ}$ group $^{\circ}$ of signals at $m / z 319(\mathbf{b}), 318(\mathbf{b}-1), 317(\mathbf{b}-2)$, and $303(\mathbf{b}$ - 16) demonstrated the structure of type I triterpenoid. The loss of $30 \mathrm{Da}$ in the $\mathrm{MS}^{3}$ spectrum was attributed to the elimination of a molecule of formaldehyde (HCHO) at C-12 (Scheme 2). Thus, Compound 1 was tentatively

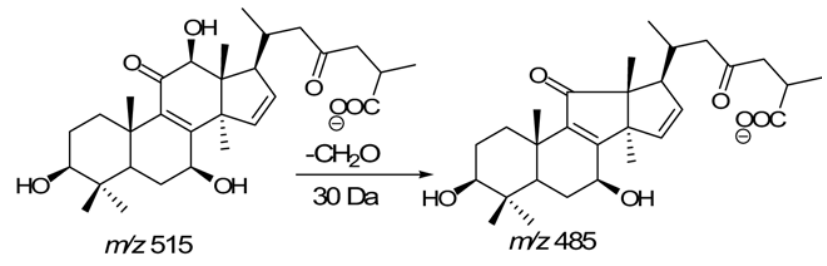

Scheme 2. Proposed fragmentation mechanism for the neutral loss of $30 \mathrm{Da}$ from ion at $\mathrm{m} / \mathrm{z} 515$ of Compound 1. 
Table 3. Characteristic ESI-MS Spectral Information for Type IV Triterpenoids

\begin{tabular}{rlrcccc}
\hline & \multicolumn{2}{c}{ Full scan $(\mathrm{m} / \mathrm{z}, \%)$} & & & \\
\cline { 2 - 3 } No. & {$[\mathrm{M}-\mathrm{H}]^{-}$} & {$\left[\mathrm{M}-\mathrm{H}-\mathrm{H}_{2} \mathrm{O}^{-}\right.$} & $\mathrm{b}$ & $\mathrm{b}-16$ & $\mathrm{~b}-18$ \\
\hline \hline 5 & $529(11)$ & $511(100)$ & 319 & 303 & 301 \\
15 & $527(91)$ & $509(100)$ & 317 & 301 & 299 \\
17 & $571(17)$ & $553(100)$ & 319 & 303 & 301 \\
18 & $615(15)$ & $597(100)$ & - & - & - \\
20 & $527(8)$ & $509(100)$ & 317 & 301 & 299 \\
29 & $613(56)$ & $595(100)$ & 361 & 345 & 343 \\
31 & $569(33)$ & $551(100)$ & 317 & 301 & 299 \\
\hline
\end{tabular}

identified as 12-hydroxyganoderic acid $\mathrm{C}_{2}$, which was reported for the first time.

\section{Identification of Type II Triterpenoids}

Ganoderic acid $\mathrm{AM}_{1}\left(\mathrm{t}_{\mathrm{R}}=24.47 \mathrm{~min}, 11\right)$ and ganoderic acid $J\left(t_{R}=59.26 \mathrm{~min}, 32\right)$ were identified by comparison with the standards. Compound $27\left(t_{R}=51.50 \mathrm{~min}\right)$ gave the $[\mathrm{M}-\mathrm{H}]^{-}$ion at $m / z 511$, which gave almost identical $\mathrm{MS}^{\mathrm{n}}(n=2$ to 4$)$ spectra to those of ganoderic acid $\mathrm{AM}_{1}$, except that the corresponding ions were lighter by two mass units. Thus, it is presumed to be a 3-oxo derivative, and was assigned as ganoderic acid $\mathrm{F}$, just bearing a different substitute at C-3 compared with ganoderic acid $\mathrm{AM}_{1}$.

\section{Identification of Type III Triterpenoids}

Ganoderic acid B $\left(t_{R}=23.14 \mathrm{~min}, 9\right), D\left(t_{R}=47.20 \mathrm{~min}\right.$, 25), $G\left(t_{R}=21.20 \mathrm{~min}, 7\right), K\left(t_{R}=26.03 \mathrm{~min}, 12\right)$, and ganoderenic acid $B\left(t_{R}=21.27 \mathrm{~min}, 8\right)$ were identified by comparison with the standards. According to the data ${ }^{\circ}$ Shown ${ }^{\circ}{ }^{\circ}$ Table $2,{ }^{\circ}$ Compounds $12\left(t_{R}=26.03 \mathrm{~min}\right)$, $22\left(t_{R}=39.77 \mathrm{~min}\right), 23\left(t_{R}=42.92 \mathrm{~min}\right)$, and $28\left(t_{R}=\right.$ $52.60 \mathrm{~min}$ ) could also be easily characterized. It was clear that Compounds $\mathbf{1 2}$ and $\mathbf{2 3}$ were ganoderenic acids (20, 22-double-bond) because their $[\mathrm{M}-\mathrm{H}]^{-}$ions had similar abundance $(>80 \%)$ to that of $[\mathrm{M}-\mathrm{H}-$ $\left.\mathrm{H}_{2} \mathrm{O}\right]^{-}$ions. Thus, Compound $\mathbf{1 2}$ must be a C-20, 22 unsaturated derivative of Compound 13 (ganoderic acid $\mathrm{K}$ ), and hence assigned as ganoderenic acid $\mathrm{K}$, which is reported for the first time. Similarly, Compound $\mathbf{2 3}$ was tentatively characterized as ganoderenic acid D.

Compounds 22 and 28 showed very similar ESI-MS ${ }^{\mathrm{n}}$ spectra to those of Compounds 7 and 13, respectively, except that the according ions were lighter by $2 \mathrm{Da}$, indicating the different substitution at C-3. Therefore, Compound 22 was assigned as 12-hydroxyganoderic acid D, and Compound $\mathbf{2 8}$ was tentatively identified as 12-acetoxyganoderic acid D.

\section{Identification of Type IV Triterpenoids}

Table $^{\circ} 3^{\circ}$ shows $^{\circ}$ the ${ }^{\circ}$ characteristic ${ }^{\circ}$ ions ${ }^{\circ}$ of ${ }^{\circ}$ type ${ }^{\circ} V^{\circ}$ triter- penoids characterized from extract of G. lucidum. These constituents have the same structural fragment bearing a hydroxyl (acetoxy) at C-12 and a keto group at C-7. Compound $17\left(\mathrm{t}_{\mathrm{R}}=31.91 \mathrm{~min}\right)$ was unambiguously identified as ganoderic acid $\mathrm{H}$ by comparison with the standard. Obviously, the peak at $18.50 \mathrm{~min}$ (5) gave identical $\mathbf{b}, \mathbf{b}-16$, and $\mathbf{b}-18$ ions to those of ganoderic acid $\mathrm{H}$. Thus, it was assumed to be a deacetylated derivative and assigned as the known compound ganoderic acid $\mathrm{C}_{6}$.

Compound $31\left(t_{R}=57.68 \mathrm{~min}\right)$ should be an acetylated derivative of Compound $\mathbf{2 0}\left(t_{R}=36.75 \mathrm{~min}\right)$. Their fragmentation behaviors were very similar to those of Compounds $\mathbf{1 7}$ and 5, respectively, except that the corresponding ions were lighter by $2 \mathrm{Da}$. We assumed that they might be the derivatives of Compound 17 and 5 by oxidizing the secondary alcohol at C-3. Thus, Compound 20 was assigned as 12-hydroxy-3, 7, 11, 15, 23-pentaoxo-lanost-8-en-26-oic acid, and Compound 31 was tentatively characterized as 12-acetoxyganoderic acid F. Similarly, Compound 29 was plausibly characterized as the new compound named 3-acetylganoderic acid $\mathrm{H}$.

The peak at $29.70 \mathrm{~min}$ (15) was an isomer of $\mathbf{2 0}$ and showed the characteristics of ganoderenic acid $\left([\mathrm{M}-\mathrm{H}]^{-}\right.$, $\left.m / z 527(91 \%) ;\left[\mathrm{M}-\mathrm{H}-\mathrm{H}_{2} \mathrm{O}\right]^{-}, \mathrm{m} / z 509(100 \%)\right)$, indicating one of the carbonyl was hydrogenized when compared with $\mathbf{2 0}$. The same $\mathbf{b}, \mathbf{b}-16$, and $\mathbf{b}-18$ ions demonstrated identical structure of $\mathrm{A}_{-}, \mathrm{B}-$, and $\mathrm{C}-$ rings to those of 20; therefore it was suggested that the carbonyl at D-ring should be hydrogenized. Thus, Compound $\mathbf{1 5}$ was tentatively identified as elfvingic acid A, a known compound isolated ${ }^{\circ}$ from $^{\circ}$ Elfoingia applanata [35].

The ESI-MS spectra of Compound $18\left(t_{R}=33.55\right.$ $\mathrm{min}$ ) were somewhat different from other type IV triterpenoids ${ }^{\circ}$ (Table 3 ). ${ }^{\circ}$ But $^{\circ}$ there ${ }^{\circ}$ was $^{\circ}$ no $^{\circ}$ doubt $^{\circ}$ that ${ }^{\circ}$ the skeleton was still similar and there were two acetoxys in the structure; one was presumably attached at C- 12 . Since no signals for $\mathbf{a}$ or $\mathbf{b}$ ion were observed, another acetoxyl group should not be attached at C-3 but C-15. Hence, the peak was tentatively characterized as 12 , 15-bis(acetoxy)-3-hydroxyl-7, 11, 23-trioxo-lanost-8-en-26oic acid, which is a new compound.

\section{Identification of Type $V$ Triterpenoids}

Compounds of this group have a $C_{27}$ lanostane skeleton. The peak at $20.16 \mathrm{~min}$ (6) was identified as $3 \beta$ hydroxy-4, 4, 14-trimethyl-7, 11, 15-trioxochol-8-en-24oic acid by comparison with the standard. The ESI-MS spectrum of Compound $24\left(t_{R}=45.92 \mathrm{~min}\right)$ gave $[\mathrm{M}-$ $\mathrm{H}]^{-}$ion at $\mathrm{m} / \mathrm{z} 455$, which was subjected to MS/MS analysis and showed very similar fragmentation pathway ${ }^{\circ}$ to $^{\circ}$ that ${ }^{\circ}$ of $^{\circ} 6$ (Table $\left.{ }^{\circ} 4\right),{ }^{\circ}$ and ${ }^{\circ}$ the ${ }^{\circ}$ corresponding ${ }^{\circ}$ ions were lighter by two mass units. It was presumed to be an oxidized derivative of 6 at C-3 and, hence, assigned as lucidenic acid $\mathrm{F}$.

The peak at $39.12 \mathrm{~min}$ (21) was an isomer of $\mathbf{6}$. The ESI-MS/MS spectrum gave abundant a $(m / z 247), \mathbf{a}+14$ 
Table 4. Characteristic ESI-MS Spectral Information for Type V Triterpenoids

\begin{tabular}{|c|c|c|c|c|c|}
\hline No. & {$\left[\mathrm{M}-\mathrm{H}-\mathrm{H}_{2} \mathrm{O}\right]^{-}$} & a & $a+14$ & b & $\mathrm{b}-14$ \\
\hline 4 & $441(100)$ & 249 & 263 & 303 & 289 \\
\hline 21 & $439(100)$ & 247 & 261 & 301 & 287 \\
\hline No. & {$[\mathrm{M}-\mathrm{H}-60]^{-}$} & $a+2$ & & $b+2$ & \\
\hline 6 & $397(100)$ & 249 & & 303 & \\
\hline 24 & $395(100)$ & 247 & & 301 & \\
\hline No. & {$[\mathrm{M}-\mathrm{H}-42-30]^{-}$} & $\mathrm{b}+2-\mathrm{HCHO}$ & & $\mathrm{b}+2-\mathrm{CH}_{4}$ & $\mathrm{e}-\mathrm{OH}$ \\
\hline 10 & $443(100)$ & 289 & & 303 & 330 \\
\hline 26 & $441(100)$ & 287 & & 301 & 328 \\
\hline No. & {$\left[\mathrm{M}-\mathrm{H}-\mathrm{H}_{2} \mathrm{O}\right]^{-}$} & b & $b-1$ & $b-2$ & $b-16$ \\
\hline 14 & 441 & 301 & 300 & 299 & 285 \\
\hline
\end{tabular}

$(\mathrm{m} / \mathrm{z} 261), \mathbf{b}(\mathrm{m} / \mathrm{z} 301)$, and $\mathbf{b}-14(\mathrm{~m} / \mathrm{z} 287)$ ions, which were somewhat similar to those of type III triterpenoids discussed above. We assumed that there should be a hydroxyl at C-7 and the C-15 should be a carbonyl, just like those of ganoderic acid D. Thus, Compound 21 was tentatively characterized as lucidenic acid A. Similarly, Compound $4\left(t_{R}=18.13 \mathrm{~min}\right)$ was assigned as lucidenic acid $\mathrm{N}$.

Compounds $10\left(t_{R}=24.09 \mathrm{~min}\right)$ and $26\left(t_{R}=48.72\right.$ min) were another couple of derivates, which just possessed the different substitutes at C-3. Therefore, they showed very similar fragmentation behaviors. The $[\mathrm{M}-\mathrm{H}]^{-}$ion at $\mathrm{m} / \mathrm{z} 513$ of $\mathbf{2 6}$ produced the prominent ion at $\mathrm{m} / \mathrm{z} 471$ in the MS/MS spectrum. The obtained ion was subjected to $\mathrm{MS}^{3}$ fragmentation, in which abundant ions at $\mathrm{m} / \mathrm{z} 287(\mathbf{b}+2-\mathrm{HCHO}), 301(\mathbf{b}+2-$ $\left.\mathrm{CH}_{4}\right)$, and $328(\mathbf{e}-17)$ were observed along with the base peak at $m / z 441\left(\left[\mathrm{M}-\mathrm{H}-42-\mathrm{HCHO}^{-}\right)\right.$. The listed ions on $\mathbf{b}+2$ indicated that C-7 of $\mathbf{2 6}$ was oxidized to be a carbonyl. Moreover, according to the $[\mathrm{M}-\mathrm{H}]^{-}$ion, 26 might be an acetoxylated derivative of lucidenic acid F (24). Thus, Compound 26 was tentatively identified as lucidenic acid D. Similarly, Compound 10 was plausibly characterized as lucidenic acid E.

Compound $14\left(t_{R}=24.09 \mathrm{~min}\right)$ was an isomer of lucidenic acid N (4). Its ESI-MS/MS spectrum gave a list of abundant ions at $m / z 301$ (b), 300 (b - 1), 299 (b - 2), and $285(\mathbf{b}-16)$, which were obviously the characteristic ions of ganoderic acid A. Thus, there should be hydroxyls attached at C-7 and C-15. Hence, Compound 14 was tentatively identified as 7, 15- dihydroxy-4, 4, 14-trimethyl-3, 11-dioxochol-8-en-24-oic acid, a compound reported for the first time.

\section{Identification of Other Compounds}

Compounds $3\left(t_{R}=16.63 \mathrm{~min}\right), 19\left(t_{R}=34.61 \mathrm{~min}\right)$, and $29\left(t_{R}=54.47 \mathrm{~min}\right)$ gave very similar ESI-MS/MS spectra. The $[\mathrm{M}-\mathrm{H}]^{-}$ion of Compound 3 was at $\mathrm{m} / \mathrm{z}$ 501 , which was 16 Da lighter than that of ganoderic acid $\mathrm{C}_{2^{\circ}}$ (Table $\left.{ }^{05}\right)$. The base ${ }^{\circ}$ peak in its ${ }^{\circ} \mathrm{MS} / \mathrm{MS}^{\circ}{ }^{\circ}$ pectrum ${ }^{\circ}$ was $\left[\mathrm{M}-\mathrm{H}-\mathrm{H}_{2} \mathrm{O}\right]^{-}$ion $\left(\mathrm{m} / z\right.$ 483), and the $\left[\mathrm{M}-\mathrm{H}-\mathrm{H}_{2} \mathrm{O}-\right.$ $\left.\mathrm{CO}_{2}\right]^{-}$ion $(\mathrm{m} / z$ 439) was abundant. Thus, this compound appeared to be a dehydroxylated derivative of ganoderic acid $C_{2}$. The known compound ganolucidic acid $B$ could match this information; therefore, its structure was plausibly characterized and the ions at $\mathrm{m} / \mathrm{z} 287$ and 289 were presumed to be $\mathbf{b}$ and $\mathbf{b}+2$, respectively. Similarly, Compound 19 was tentatively characterized as ganolucidic acid $\mathrm{A}$.

Compound 29 was an isomer of 19. $\left[\mathrm{M}-\mathrm{H}-\mathrm{H}_{2} \mathrm{O}\right]^{-}$ $(m / z 481),\left[\mathrm{M}-\mathrm{H}-\mathrm{H}_{2} \mathrm{O}-\mathrm{CO}_{2}\right]^{-}(\mathrm{m} / z$ 437), $\mathbf{b}(\mathrm{m} / z$ 285), and $\mathbf{b}+2(\mathrm{~m} / \mathrm{z} 287)$ ions were observed in its MS/MS spectrum. Interestingly, $\left[\mathrm{M}-\mathrm{H}-\mathrm{H}_{2} \mathrm{O}-\mathrm{CO}_{2}\right]^{-}$ion was the base peak. We assumed it might be ganolucidic acid $\mathrm{D}$, which had a different side chain at C-17 compared with ganolucidic acid $\mathrm{A}$.

\section{Conclusions}

In this study, the fragmentation behavior of triterpenoids, which shared the same core triterpene structure as $C_{30}$ or $C_{27}$ lanostane, in electrospray ion trap mass spectrometer was studied. The predominant fragmentation pathways were losses of $\mathrm{H}_{2} \mathrm{O}$ and $\mathrm{CO}_{2}$, but their characteristic behaviors were cleavage of C- and Drings. Different substitution at C-7, 12, 15 resulted in different fragmentation and the double-bond at C-20, 22 would also affect the behaviors of mass spectra.

Using HPLC-DAD-ESI-MS and $\mathrm{MS}^{\mathrm{n}}$ ( $n=2$ to 4 ), we have demonstrated the assignment of 26 known triterpenoids along with six previously unidentified compounds of Ganoderma lucidum. For analysis of triterpenoids in crude extract, we recommended the initial application of negative ion ESI-MS to obtain the molecular mass information for the components via the [M $\mathrm{H}]^{-}$ions, and to determine the structural information by acquiring $\mathrm{MS}^{\mathrm{n}}$ spectra. The observed $[2 \mathrm{M}-\mathrm{H}]^{-}$ions were found very useful for peak confirmation. Construction of a library containing $\mathrm{MS}^{\mathrm{n}}$ spectra for known triterpenoids would greatly facilitate the identification

Table 5. Characteristic ESI-MS Spectral Information for Compounds 3, 19, and 30

\begin{tabular}{rcccc}
\hline No. & {$\left[\mathrm{M}-\mathrm{H}-\mathrm{H}_{2} \mathrm{O}\right]^{-}$} & {$\left[\mathrm{M}-\mathrm{H}-\mathrm{H}_{2} \mathrm{O}-\mathrm{CO}_{2}\right]^{-}$} & $b$ & $b+2$ \\
\hline \hline 3 & $483(100)$ & $439(49)$ & 287 & 289 \\
19 & $481(100)$ & $437(77)$ & 285 & 287 \\
30 & $481(60)$ & $437(100)$ & 285 & 287 \\
\hline
\end{tabular}


of these compounds in real samples and would permit even more complete fingerprinting of triterpenoids that arise from species differences of different Ganoderma extracts.

\section{Acknowledgments}

The authors thank the financial support of this work by a program for Changjiang Scholar and Innovative Team in University (grant number 985-2-063-112) and Green Valley Pharmaceutical Co. Ltd.

\section{References}

1. Xie, J. T.; Wang, C. Z.; Wicks, S.; Yin, J. J.; Kong, J.; Li, J.; Li, Y. C.; Yuan, C. S. Ganoderma lucidum Extract Inhibits Proliferation of SW 480 Human Colorectal Cancer Cells. Exp. Oncol. 2006, 28, 25-29.

2. Liu, G. Q.; Zhang, K. C. Mechanisms of the Anticancer Action of Ganoderma lucidum (Leyss. ex Fr.) Karst: A new understanding. J. Integr. Plant. Biol. 2005, 47, 129-135.

3. Yuen, J. W. M.; Gohel, M. D. I. Anticancer Effects of Ganoderma lucidum: A review of scientific evidence. Nutr. Cancer 2005, 53, 11-17.

4. Petrova, R. D.; Wasser, S. P.; Mahajna, J. A.; Denchev, C. M.; Nevo, E. Potential Role of Medicinal Mushrooms in Breast Cancer Treatment: Current Knowledge and Future Perspectives. Int. J. Med. Mushrooms 2005, 7, 141-155

5. Lin, Z. B.; Zhang, H. N. Antitumor and Immunoregulatory Activities of Ganoderma lucidum and Its Possible Mechanisms. Acta Pharmacol. Sin. 2004, 25, 1387-1395.

6. Gao, Y. H.; Zhou, S. F. Chemopreventive and Tumoricidal Properties of Lingzhi Mushroom Ganoderma lucidum (W.Curt.:Fr.) Lloyd (Aphyllophoromy cetideae). Part II. Mechanism considerations (review). Inter. J. Med. Mushrooms 2004, 6, 219-230

7. Lee, S. Y.; Rhee, H. M. Cardiovascular Effects of Mycelium Extract of Ganoderma lucidum: Inhibition of Sympathetic Outflow as a Mechanism of Its Hypotensive Action. Chem. Pharm. Bull 1990, 38, 1359-64.

8. Chen, R. Y.; Yu, D. Q. Advances of Triterpenoids Constituents of Ganoderma lucidum. Acta Pharmacol. Sin. 1990, 25, 940-953.

9. Luo, J.; Lin, Z. B. Advances of Pharmacological Effects of Triterpenes from Ganoderma lucidum. Acta Pharmacol. Sin. 2002, 37, 574-578.

10. Liu, J.; Shimizu, K.; Konishi, F.; Noda, K.; Kumamoto, S.; Kurashiki, K.; Kondo, R. Antiandrogenic Activities of the Triterpenoids Fraction of Ganoderma lucidum. Food Chem. 2007, 100, 1691-1696.

11. Li, Y. Q.; Wang, S. F. Antihepatitis B Activities of Ganoderic Acid from Ganoderma lucidum. Biotechnol. Lett. 2006, 28, 837-841.

12. Pillai, T. G.; Bincy, C. P.; Janardhanan, K. K. Antioxidant Activity of Terpenes Isolated from Ganoderma lucidum. Amala. Res. Bull 2004, 24, 185-190

13. Huang, S. M.; Yang, X. L.; Wang, B. W.; Zhu, H. S.; Xu, J. L. Antitumor Activity of Ethanol-Soluble and Acidic Components from Ganoderma lucidum. Nat. Prod. Res. Dev. 2004, 16, 146-148.

14. Min, B. S.; Gao, J. J.; Hattori, M.; Lee, H. K.; Kim, Y. H. Anticomplement Activity of Terpenoids from the Spores of Ganoderma lucidum. Planta. Med. 2001, 67, 811-814.

15. Min, B. S.; Gao, J. J.; Nakamura, N.; Hattori, M. Triterpenes from the Spores of Ganoderma lucidum and Their Cytotoxicity Against Meth-A and LLC Tumor cells. Chem. Pharm. Bull 2000, 48, 1026-1033.

16. Li, P. Z.; Zhang, K. C. Isolation, Purification, and Antimicrobial Activity of Ganoderic Acids M1-M3 from the Fermented Mycelia of Ganoderma lucidum. Nat. Prod. Res. Dev. 1999, 11, 67-70.
17. Zhu, M.; Chang, Q.; Wong, L. K.; Chong, F. S.; Li, R. C. Triterpene Antioxidants from Ganoderma lucidum. Phytother. Res. 1999, 13, 529-531.

18. Min, B. S.; Nakamura, N.; Miyashiro, H.; Bae, K. W.; Hattori, M. Triterpenes from the Spores of Ganoderma lucidum and Their Inhibitory Activity Against HIV-1 Protease. Chem. Pharm. Bull 1998, 46, 1607-1612.

19. Mizushina, Y.; Takahashi, N.; Hanashima, L.; Koshino, H.; Esumi, Y.; Uzawa, J.; Sugawara, F.; Sakaguchi, K. Lucidenic Acid O and Lactone, New Terpene Inhibitors of Eukaryotic DNA Polymerases from a Basidiomycete, Ganoderma lucidum. Bioorg. Med. Chem. 1999, 7, 2047 2052.

20. Morigiwa, A.; Kitabatake, K.; Fujimoto, Y.; Ikekawa, N. Angiotensin Converting Enzyme-Inhibitory Triterpenes from Ganoderma lucidum. Chem. Pharm. Bull 1986, 34, 3025-3028.

21. Ye, M.; Han, J.; Chen, H. B.; Zheng, J. H.; Guo, D. A Analysis of Phenolic Compounds in Rhubarbs Using Liquid Chromatography Coupled with Electrospray Ionization Mass Spectrometry. J. Am. Soc. Mass Spectrom 2007, 18, 82-91.

22. Ye, M.; Guo, D. A.; Ye, G.; Huang, C. G. Analysis of Homoisoflavonoids in Ophiopogon japonicus by HPLC-DAD-ESI-MS n. J. Am. Soc. Mass Spectrom. 2005, 16, 234-243.

23. Yang, M; Liu, A. H.; Guan, S. H.; Sun, J. H.; Xu, M.; Guo, D. A Characterization of Tanshinones in the Roots of Salvia miltiorrhiza (Dan-shen) by High-Performance Liquid Chromatography with Electrospray Ionization Tandem Mass Spectrometry. Rapid Commun. Mass Spectrom. 2006, 20, 1266-1280.

24. Liu, R. X.; Ye, M.; Guo, H. Z.; Bi, K. S.; Guo, D. A. Liquid Chromatography/Electrospray Ionization Mass Spectrometry for the Characterization of Twenty-Three Flavonoids in the Extract of Dalbergia odorifera. Rapid Commun. Mass Spectrom. 2005, 16, 1557-1565.

25. Sye, W. F. Improved Method of Extraction and High-Performance Liquid Chromatographic Separation of Ganoderic Acids from Ganoderma lucidum. J. Chin. Chem. Soc. 1991, 38, 179-182.

26. Zhang, J.; Zhang, L. H.; Duan, J. C.; Liang, Z. Zhang, W. B.; Huo, Y. S.; Zhang, Y. K. On-Line Hyphenation of Supercritical Fluid Extraction and Two-Dimensional High Performance Liquid Chromatography-Atmospheric Pressure Chemical Ionization Tandem Mass Spectrometer for the Analysis of Ganoderma lucidum. J. Sep. Sci. 2006, 29, 2514-2522.

27. Kohda, H.; Tokumoto, W.; Sakamoto, K.; Fujii, M.; Hirai, Y; Ymasaki, K.; Komoda, Y.; Nakamura, H.; Ishihara, S.; Uchida, M. The Biologically Active Constituents of Ganoderma lucidum (Fr.) Karst Histamine ReleaseInhibitory Triterpenes. Chem. Pharm. Bull 1985, 33, 1367-1374.

28. Kikuchi, T.; Matsuda, S.; Kadota, S.; Murai, Y.; Ogita, Z. Ganoderic acid D, E, F, and $\mathrm{H}$ and Lucidenic Acid D, E, and F; New Triterpenoids from Ganoderma lucidum. Chem. Pharm. Bull 1985, 33, 2624-2627.

29. Morigiwa, A.; Kitabatake, K.; Fujimoto, Y.; Ikekawa, N. Angiotensin Converting Enzyme-Inhibitory Triterpenes from Ganoderma lucidum. Chem. Pharm. Bull 1986, 34, 3025-3028.

30. Nishitoba, T.; Sato, H.; Sakamura, S. New Terpenoids, Ganoderic Acid $\mathrm{J}$ and Ganolucidic Acid C, from the fungus Ganoderma lucidum. Agric. Biol. Chem. 1985, 49, 3637-3638.

31. Lin, C. N.; Kuo S. H.; Won, S. J. Steroids of Formosan Ganoderma amboinense. Phytochemistry 1993, 32, 1549-1551.

32. Komoda, Y.; Nakamura, H.; Ishihara, S.; Uchida, M.; Kohda, H.; Ymasaki, K. Structures of New Terpenoid Constituents of Ganoderma lucidum (Fr.) Karst (Polyporaceae). Chem. Pharm. Bull 1985, 33, 4829 4835

33. Guan, S. H.; Yang, M.; Liu, X.; Xia, J. M.; Wang, X. M.; Jin, H.; Guo, D. A Two New Lanostanoid Triterpenes from the Fruit Body of Ganoderma lucidum - the Major Component of SunRecome. Nat. Prod. Commun. 2006, 1, 177-181.

34. Wang, X. M.; Yang, M.; Guan, S. H.; Liu, R. X.; Xia, J. M.; Bi, K. S.; Guo, D. A. Quantitative Determination of Six Major Triterpenoids in Ganoderma lucidum and Related Species by High Performance Liquid Chromatography. J. Pharm. Biomed. Anal. 2006, 41, 838-844.

35. Yoshikawa, K.; Nishimura, N.; Bando, S.; Arihara, S.; Matsumura, E.; Katayama, S. New Lanostanoids, Elfvingic Acids A-H, from the Fruit Body of Elfvingia applanata. J. Nat. Prod. 2002, 65, 548-552. 